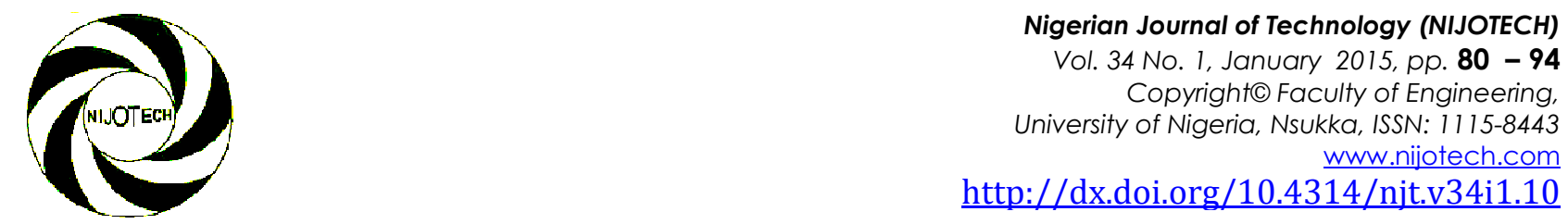

\title{
REVIEW OF ELASTIC ANALYSIS OF BOX GIRDER BRIDGES
}

\author{
G. C. Ezeokpube* \\ DEPARTMENT OF CiVIL ENGINEERING, MiCHAEL OKPARA UNIVERSITY OF AGRICULTURE UMUDIKE, NIGERIA \\ E-mail Address: engrgreg2006@yahoo.com
}

\begin{abstract}
The importance of thin-walled box girder bridges has attracted the attention of researchers since the last five decades. A lot of literature has dealt with the analytical formulations as well as experimental investigations. Field studies have increased tremendously in the last decade. So far the agreement between the analytical and experimental results has been excellent and, therefore, has made it possible to augment a limited number of experimental tests with hundreds of analytical studies. Highlights of research efforts in published literature regarding the analysis methods and experimental studies related to the elastic analysis of box girder bridges have been presented in this review. Subjects discussed include: (1) Thin -Walled Curved Beam Theory; (2) BEF/EBEF Method; (3) Finite Segment Method; (4) Folded Plate Method; (5) Finite Difference Method; (6) Energy Variational Principle; (7) Grillage Analogy and Space Frame Methods; (8) Finite Element Method; (9) Finite Strip Method; (10) Simplified/Miscellaneous Methods; (11) Experimental Studies.
\end{abstract}

Keywords: box girder; bridges; elastic analysis; thin-walled and reviews.

\section{INTRODUCTION}

A lot of analytical and experimental studies on the static, dynamic, and stability analyses of thin-walled box girders has been presented in journals by many researchers. A comprehensive review of analytical and experimental studies on box-girder bridges was undertaken by Maisel [1] in England. This comprehensive review was extended by Swann [2], Maisel et al. [3],and Maisel [4].

Sennah and Kennedy [5] provided a review of research work on box girder bridge design topics. These topics include box girder bridge configurations; construction issues, load distribution, dynamic response, and ultimate load carrying capacity. The review reported difficulties encountered in box girder construction such as changes in geometry and excessive rotation of girders before and during the placement of the concrete deck. The primary conclusion regarding the construction and design of curved box girders is that the current North American codes, including AASHTO [6] publications and Canadian [7] codes, as well as published literature, do not provide the design engineer with adequate information on the behavior of unshored straight and curved box girder bridges during construction. Additional research work using 3-D finite element analysis is needed to avoid potential catastrophic failures [5].

In another review by Sennah and Kennedy [8], analysis methods used to analyze box girder bridges systems found in the literature were presented. The review concluded that, although the finite element method seems to be the most costly and time consuming, it is the most detailed and comprehensive method that can overcome the limitations of other simplified methods. Moreover, issues such as thermal effects are difficult to model accurately, except through a detailed finite element analysis. It recommended that a survey on the available software for the cumulative analysis of bridge structures through the construction, service, and ultimate phases (time-dependent analysis) would be useful for designers. This would apply to the design of new bridges and rating of existing bridges. Each of both reviews by Sennah and Kennedy [5, 8] provide a comprehensive list of more than 150 references.

Davidson et al. [9] presented a synthesis of curved steel bridge research literature and current practice for both I-girder and box girder superstructure configurations. More than 200 literature sources, up to the year 2003, were collected, reviewed, analyzed and integrated into the synthesis. Kulicki et al. [10] 
presented a comprehensive up-to-date literature review for publications from July 1993 to the year 2000 , describing research works related to design and analysis of horizontally curved steel box-girders and Igirders. General references on analysis methodology that may have applied to both steel and concrete were retained. In all, ninety-six references were identified of which 91 abstracts were presented.

Considering the fast pace of developments in bridge engineering, it becomes pertinent to carry out periodic reviews of the analytical and experimental processes in the face of emerging technologies and improving analytical tools. Therefore, this paper presents up-to-date research efforts in published literature regarding the analysis methods and experimental studies related to the elastic analysis of box girder bridges and to provide recommendations for further research works. Subjects discussed include: (1) Thin -Walled Curved Beam Theory; (2) BEF/EBEF Method; (3) Finite Segment Method; (4) Folded Plate Method; (5) Finite Difference Method; (6) Energy Variational Principle; (7) Grillage Analogy and Space Frame Methods; (8) Finite Element Method; (9) Finite Strip Method; (10) Simplified / Miscellaneous Methods; (11) Experimental Studies.

\section{METHODS EMPLOYED FOR ANALYSIS OF BOX- GIRDER BRIDGES}

\subsection{Thin-walled Curved Beam Theory}

The curved beam theory was first established by Saint-Venant [11] for the case of solid curved beams loaded in a direction normal to their plane of curvature. Benscoter [12] applied this theory to multicell beams. In general, curved beam theory cannot be applied to curved box-girder bridges, because it cannot account for warping, distortion, and bending deformations of the individual wall elements of the box. According to Fan and Helwig [13], Vlasov [14] was the first to study distortion of box-girders while investigating the torsional behavior of thin-walled beams with closed cross-section. Vlasov [5] presented the thin-walled beam theory for axisymmetric sections. Vlasov's thin-walled beam theory was extended by Dabrowski $[16,17,18]$ for asymmetric section, to account for warping deformations caused by the gradient of normal stresses in individual box elements. Review by McManus [19] showed that Gottfield [20]and Umanskii [21] also contributed to the development of the curved beam theory. A more detailed review of the early developments in the thin- walled curved beam theory was given by Sennah and Kennedy [8].

Kermani and Waldron [22] presented a method of analysis that allows for the effects of cross-sectional distortion in addition to those of torsional warping. The method is a rational extension of thin-walled beam theory and may be applied to simply supported or continuous box girders of either straight or curved configuration.

Razaqpur et al. [23, 24] used the straight thin-walled box beam element, along with exact frequencydependent shape functions for dynamic vehicle-box girder bridge interaction. The vehicle was modeled by one axle with sprung and unsprung masses connected by a system of springs and dashpots. Wu et al. [25] developed a finite beam element for analyzing shear lag and shear deformation effects in compositelaminated box girders. Through the numerical examples it was concluded that the procedure possesses better efficiency in the analysis of symmetric composite single-cell box beams. Park et al. $[26,27]$ developed thin-walled box beam finite element for straight multicell box girder bridges and horizontally curved box girder bridges respectively. The validations of the proposed models were demonstrated through a series of comparative studies using conventional shell elements. Presentations of the basic theory of thin-walled beams including flexure, torsion, distortion, and stress distribution are provided in several texts $[14,18,28,29,30,31]$.

The thin-walled beam theory has the following limitations. It is highly involved with very rigorous and lengthy procedures such that structural analysts often shy away from using it for practical analysis of box girder bridges.

\subsection{BEF/EBEF Method}

BEF (Beam on Elastic Foundation) analogy is one of the most conventional methods of predicting warping and distortional stresses in Box Girder Bridges [32]. The BEF analogy was first noted by Vlasov [14]. Wright et. al. [33] further developed the Vlasov [14] proposed equation and then utilized it for distortional analysis of box girders, but it is limited only to prismatic straight box girders. Kristek [34] extended the BEF analogy to distortional analysis of box girders with tapered deformable cross section. A modified approach called the EBEF (Equivalent Beam on Elastic Foundation) method was developed and presented by Hsu et al., [35] to analyze the BEF problem using a matrix approach. The study concluded that the 
analysis of closed (or quasi-closed) box girder bridges, using the EBEF method, provides a simplified procedure to account for the deformation of the cross section for the effect of rigid or flexible interior diaphragms and continuity over supports. While the traditional BEF analysis is based on the Fourier series solution, the EBEF method uses a finite element formulation [36].

The BEF and EBEF methods have the following shortcomings. The BEF method is limited only to prismatic straight box girders. Though the EBEF method is an enhancement of the BEF method, both methods still ignores the effect of shear deformation which has been shown [32] to be substantial in distortional analysis of box girder bridges.

\subsection{Finite Segment Method}

The finite segment method, based on the ordinary theory of folded plates, may be applied to structures with arbitrary end and interior support conditions. It gives accurate results for deflections and the distribution of the total moments at a section to each longitudinal girder. Scordelis [37] applied the finite segment method for the analysis of continuous box girder bridges.

Yang et al. [38] developed the stochastic finite segment method (SFSM) and applied it to the analysis of shear lag effect on box-girder. An example was given to demonstrate the efficiency and accuracy of the method. Results were compared with the analytical variational solutions and those achieved by the technique of direct Monte Carlo simulation and the finite strip, respectively, showing desirable agreement.

Lou et al. [39, 40, 41, 42] used model tests and finite segment method to investigate shear lag effects in thin-walled box girders. The study revealed that negative shear lag not only exists in cantilever and continuous box girders but also in simply supported box girders with varying depth. Wang et al. [43] presented an efficient finite segment approach for the analysis of a curved box girder with corner stiffeners. The shear lag effect and local flexure behavior of curved box girder structures were taken into consideration in the formation. Numerical results showed that the effect of the corner stiffners should not be neglected in the design of curved box-girder bridge.

\subsection{Folded Plate Method}

The folded plate equations were originally derived by Goldberg and Leve [44] and applied to a direct stiffness solution for folded plate structures by DeFries-Skene and Scordelis [45]. The method was applied to cellular structures by Al-Rifaie and Evans [46], and Evans [47]. The Canadian High-way Bridge Design Code [7] restricted this method to bridges with support conditions closely equivalent to line supports at both ends of the bridge. Marsh and Taylor [48] developed a method that incorporates a classical folded plate method for the analysis of box girders.

The folded plate method has the following shortcomings. It is restricted to continuous structures that are simply supported at the extreme ends and to cases in which the material and dimensional properties of each plate making up the cross-section are constant, both longitudinally and transversely (isotropic material properties). Additionally the method is complicated and time-consuming.

\subsection{Finite Difference Method}

Researchers $[49,50]$ used the finite difference method for the analysis of Box Girder Bridges. Oleinik [51], Olieniek and Heins [52], Heins and Oleinik [53] presented a computer program, based on the finite difference method, for solving differential equation that describes the behavior of curved box girders.

The finite difference method has the following limitation. The efforts needed to analyse a box girder bridge by the finite difference method is cumbersome and time-consuming. Accuracy of results can be expected only if fine grids are used.

\subsection{Energy Variational Principle}

The theorem of minimum potential energy is the most general of the energy variation principles applied in the analysis of Box Girders. Reissner [54, 55, 56], used the energy variation principle for shear lag analysis of doubly symmetric rectangular box beam assuming the longitudinal displacement along transverse direction is described by a parabolic curve. Kuzmanovic and Graham [57], Dezi and Mentrasti [58], and Wu et al. [59] used the energy variational principles for shear lag analysis of thin-walled box girders.

Yapping et al [60] used the principle of minimum potential energy to developed a model capable of analyzing the static behavior (including effects of shear lag and shear deformation, ply normal stress, etc) of symmetrically laminated thin-walled composite box beams under bending load. The numerical analysis results correlates very well with the results of finite element (ANSYS) analysis and that of model test. It was concluded that the shear lag and 
shear and shear deformation significantly affect the strength and stiffness characteristics of composite box beams, but can be adjusted by changing the ply angle of the layer in the analysis and design of composite box beams.

Hamed and Frostig [61] used the variational principle of virtual work following Hamilton's principle, to develop an analytical model for the free vibration behavior of multi-girder and multi-cell box bridges, including transverse deformation effects. The results of the proposed model were validated through comparison with three-dimensional finite element models. It was concluded that the transverse deformations decrease the magnitudes of the eigenfrequencies of the torsional mode shapes, as well as the high flexural modes.

Osadebe and Mbajiogu [32] used the energy variational principle on the assumption of Vlasov [15] theory to derive a fourth order differential equation of distortional equilibrium for thin-walled single cell box girder structures. The results of analysis showed that the effect of shear deformations can be substantial and should not be disregarded under distortional loading.

Wen [62] presented a revised method for improvement of shrinkage and creep prediction in prestressed box-girder bridge widening, by incremental method was base on the energy principle. A calculatory program was complied according to this method, which was validated by test results. Test and analytical result proved the proposed method to be very effective.

The major limitation of the energy variation principle is that it is not applicable to the analysis of Box girders with variable depth [42].

\subsection{Grillage Analogy and Space Frame Methods}

Two-dimensional continuum of the bridge deck could be idealized into an assemblage of beam elements in two perpendicular directions. These beam elements form the grillage [63]. The grillage analogy method is a computer-oriented technique, being used in the analysis and design of bridges [64]. Song et al. [65] presented a study on the live-load distribution characteristics of box-girder bridges and the limits imposed by the AASHTO Load and Resistance Factor Design (LRFD) specifications [66]. A grillage model, verified with a finite element method, was used in the analytical investigation. The study concluded that analytical results indicated that the current LRFD distribution factor formulas generally provide a conservative estimate of the design bending moment and shear force.

In the space frame method the bridge system is idealized into a number of beam-column elements. The space frame method, like the grillage analogy method, is one of the macromodelling techniques. Macromodelling techniques are simple to implement and, because they yield reasonable results are commonly used by practitioners and researchers. Okeil and El-Tawil [67] used the space frame method to present a detailed investigation of warping stresses in curved box girder bridges.

Both the space frame and grillage analogy methods have the following limitation. The grillage analogy and the space frame method are macromodelling techniques in which case the focus in analysis is on forces rather than stresses [67]. Unlike the finite element and finite strip methods, the macromodelling techniques cannot easily be used directly to provide detailed and accurate information on stresses.

\subsection{Finite Element Method}

The finite element methods have no restrictions on its application to problems with arbitrary geometry, boundary conditions and material variations. It is regarded as the most general and comprehensive technique for the static and dynamic analysis of most engineering continuum structures including box girder bridges. Several research studies on the analysis of box girder bridges using the finite element method, have been presented.

Yabuki et al. [68] presented a nonlinear finite-element method for predicting the influence of local buckling in component plates and distortional phenomenon on the ultimate strength of thin-walled, welded steel box girders curved in plan. Theoretical predictions, obtained using the proposed method, were compared to experimental results. Reasonable agreement between tests and theory was observed. Shu and Wang [69] investigated the stability characteristics of box-girder cable-stayed bridges by three-dimensional finite-element methods. The study concluded that the use of A-type or H-type pylons on this type of bridge has no distinguishable difference on the numerical results of the buckling analysis. Prokic [70] developed a new finite element model on the basis of the wrapping function proposed by Prokic [71, 72], for shear lag analysis of wide-flanged thin-walled boxgirders. The numerical results obtained by using the model are in close agreement with the theoretical and test results of other authors. 
Lee et al. [73] studied shear lag anomaly in box girders using the finite element method. The research concluded that shear lag anomaly (or negative shear lag) can take place whenever the portion of the shear flow acting along the flanges, which produces the shear lag-after effect, is larger than the remaining portion of shear flow caused by positive shear lag. Though this conclusion was strongly supported by Lee et al. [74], it was at variance with the findings of Rovnak and Duricova $[75,76]$ and that of Rovnak and Rovnakova [77] as well.

Lertsima et al. [78] investigated the stress concentration in a flange due to shear lag in simply supported box girder by the three-dimensional finite element method using shell elements. They observed that, although much research has been done on the shear lag phenomenon and several design codes [79, $80,81]$ have provided formulas to account for the shear lag effect, discrepancies in numerical results are observed in the literature. The study concluded that stress distributions both in the flange and in the web can be very different from those of the elementary theory. Based on the numerical results obtained, empirical formula were proposed to compute stress concentration factors due to shear lag.

Yoon et al. [82] presented a series of parametric studies on the effect of access holes on the strength of the load-bearing diaphragms in steel box girder bridges using three-dimensional finite element method. The research concluded that the location of the access hole has no detrimental effect on the diaphragm strength. Kurian and Menon [83] used a three-dimensional finite element analysis to study the errors in simple frame analysis (SFA) of simply supported concrete box-girder bridges. It was established that there could be significant errors in the use of SFA for the purpose of estimating the design transverse moments under vehicular loads. Accordingly, a set of correction factors to the result of SFA were proposed, which is expected to be of significant use in design practice.

Zhou [84] showed that the effect of shear lag on the redistribution of internal forces in indeterminate boxgirder bridges is too small to be neglected and that the calculated accuracy for internal forces by using the general finite-element method (excluding the shear lag effect) can satisfy the requirement of engineering application. Zhang and Luo [85] presented a study on patch loading and improved measures of incremental launching of Yandangshan Bridge a steel box girder in China. The launching process was monitored and measured stress and deformation coincide with the results of finite element analysis. The research concluded that the incremental launching of the steel box girder of Yandangshan Bridge was successful.

Kim and Fam [86] Proposed a three-dimensional finite element (FE) model to predict the behavior of pultruded GFRP box girders supporting adhesivelybonded concrete deck in flexure. The method of analysis was validated by experiment. The study examined the single girder behavior as well as girdergroup systems, to assess load distribution. It was shown that the AASHTO-LRFD [87] approach for load distribution can reasonably be used for the proposed girder systems.

Lei at al. [88] used the finite element analysis to develop the distribution laws of the eccentric load coefficient of continuous composite box-girder bridge with corrugated steel webs. The results of the analysis compared favorably with several simplified methods commonly used in engineering. The research recommended that it would not be advisable to use uniform eccentric load coefficient of each section along the bridge. Ding et al. [89] established a three dimensional finite element model of Presressed Concrete (PC) box-girder with corrugated steel webs taking material nonlinearity into consideration to investigate the behavior under pure torsion. The torque-twist curves and ultimate torsional strength predicted by FEM show good agreement with test data. It was shown that the ultimate torsional strength of specimens is in linear proportion to shear modulus compressive strength of concrete.

The major disadvantage of the finite element method is that it is time-consuming and involves a lot of computational efforts.

\subsection{Finite Strip Method}

The finite strip method (FSM) can be considered as a kind of finite element method (FEM) in which a special element called the strip is used [90]. FSM can, therefore, be regarded as a degenerate form of FEM which is used to primarily model the response of prism-like structures such as plates and solids [91]. The aim of FSM is not to replace entirely the FEM but compliment it where FSM is more effectively used for the analysis of structures with geometry of a large length in the longitudinal direction and relatively short transverse length such as box-girder bridges [92]. For bridges having regular geometric plans and simple boundary conditions, a full finite element analysis is often both extravagant and unnecessary 
[93]. The cost of solution can be high and usually jumps by an order of magnitude when a more refined higher dimensional analysis is required [94]. While FEM usually requires large quantities of input data and thus more chances to make mistakes, the process of analysis and input handling used in FSM are very simple and convenient [92].

The first research study on the analysis of box girder bridges using the finite strip method was presented by Cheung [95]. Later on Cheung and Cheung [96] presented a study on the analysis of curved box Girder Bridge using the finite strip method. Since then a lot of studies, on the finite strip analysis of box girder bridges and folded plate structures, has been presented. The $\mathrm{B}_{3}$ spline function was introduced as the longitudinal displacement function by Cheung et al. [97]. The spline finite strip method can include any types of boundary condition and more easily simulate peak values of bending moments at loaded sections and intermediate supports. In later years, the spline finite strip method was extended to right box girder bridges by Cheung and Fan [98].

Arizumi et al. [99] studied the distortional and slip behavior of simply supported curved composite box girder bridges using the finite strip method. The results from the proposed finite-strip method compared favorably to those obtained from curved beam theory, distortional theory, and static tests. Bradford and Wong [100] used the finite strip method to evaluate the local buckling of composite box sections in negative bending. The values obtained from this method were used to develop design charts to determine the buckling coefficient of the web. The design charts illustrate that increasing the flange width would decrease the restraining effect of the flange, and hence lower the buckling coefficient. The charts showed that, as the neutral axis moves higher, the buckling coefficients decreases.

Choi et al. [92] presented the analysis of prestressed box-girder bridges using the spline finite strip method. In the study, the spline finite strip method was modified by using the non-periodic B-spline interpolation. Several examples were analyzed to verify the performance of the present method. Good agreements were obtained when compared with the previous studies.

Taysi and Ozakca [101] developed a computational tool, using the finite strip method, for the geometric modeling, free vibration analysis and shape optimization of box girder bridges. The study concluded that the finite strip method (FSM) offers an accurate and inexpensive tool for the optimization of box-girder bridges having regular prismatic-type geometry with diaphragm ends. Halkude and Akim [93] presented a study on the analysis of straight and skewed box girder bridge by the finite strip method. Based on the results of analysis, the study concluded that the longitudinal bending moment, $\mathrm{M}_{\mathrm{y}}$, decreases and the twisting moments, $M_{x y}$, increase with the skew angle. Ezeokpube [102] developed a MATLAB computer program for the finite strip analysis of continuous thin-walled box girder bridges. The program was validated with experimental studies and by comparison of results with literature. Texts by Cheung [94], Loo and Cusens [103], Cheung et al. [91], Cheung and Tham [104], summarized the basic theory of the finite strip method and its applications in bridge engineering.

The finite strip method has the following shortcoming. As a degenerate form of the finite element method, there are restrictions on the application of the finite strip method to problems with arbitrary geometry, boundary conditions and material variations. The finite strip method has been successful in dynamic analysis for all cases of end support conditions but is especially effective in static analysis only if two opposite ends of the structure are simply supported.

\subsection{Simplified /Miscellaneous Methods}

Simplified Methods are often employed in practice to avoid the rigours of three-dimensional analysis. Knittle [105], Richmond [106] and Kupfer [107] developed simplified methods to predict the transverse behavior due to the action of concentrated loads acting directly on top webs. Tung and Fountain [108] presented an Approximate Method for Torsion Analysis of Curved Box Girders by the Moment/Radius of curvature (M/R) method.

Chang and Zheng [109], and Chang [110] developed a differential equation, including the shear lag effect, for a rectangular thin-walled box girder having a cantilever length that is equal to half the clear width of the box. Galuta and Cheung [111] developed a hybrid analytical solution which combines the boundary element method (BEM) with the conventional finite element method (FEM). The combined method (BEMFEM) was effectively applied to the analysis of boxgirder bridges. The results obtained were in good agreement with the finite strip solution.

Oh and In [112] proposed a method to predict timedependent prestress force changes due to creep and shrinkage in prestressed concrete (PSC) Box Girder 
Bridges. Chusilp and Usami [113] presented practical methods for predictions of strength and ductility capacity of thin-walled steel box girders with longitudinally stiffened webs predominantly loaded in shear. Considering key structural parameters, a simple formula was proposed for the assessment of the ductility capacity. Fan and Helwig [13] developed approximate equations for brace forces in internal Kframe bracing members for quasi-closed curved trapezoidal box girders. The equations, which were verified by three dimensional FEA, are fundamental for studying distortional stresses and brace forces in curved box girders.

Luo et al. [114] proposed a new approach for the calculation of moments on top slab in single-cell box girders, using the classical thin plate theory and trigonometric series. Upadyay and Kalyanaraman [115] presented a simplified procedure for the analysis of single cell FRP box-girder bridges made of blade angle and T-stiffened panels. This was validated by comparison with results available in literature or results obtained from finite element analysis. Shirai and Ueda [116] used a numerical method for the study of aerodynamic simulation by CFD on flat box girder of super-long-span suspension bridge. The calculated results of the aerodynamic behavior compared favorably with experimental data reported by Matsumoto et al. [117].

Yang [118] proposed a method of uncertainty analysis and sensitivity analysis of the effects of creep and shrinkage in prestressed concrete (PSC) box girder bridges. The Latin hypercube simulation technique was used to study the uncertainty of model parameters. Based on the study, it was concluded that the proposed method can be efficiently used to perform a sensitivity analysis of time-dependent effects of PSC box girder bridges. Moon et al. [119] investigated the stress variation and deformation characteristics of a segment box girder bridges during construction, using a sequence analysis. The study concluded that the structural behavior of the girder sections was greatly affected by the thickness of the bottom slab and the position of prestressing anchors, but not by the prestressing sequence. Based on the results, a construction method for crack control was proposed.

Mori et al. [120] investigated quantitatively the effects of structural and traffic conditions on the fatigue life of short and medium span box-girder steel highway bridges. It was concluded that the results of the study could be conveniently used to find out under what condition a steel bridge is apt to be damaged by fatigue in the stage of design and maintenance. Sawar and Ishihara [121] investigated the mechanism of reduction in the amplitude of vortex-induced vibrations for a box girder section in the presence of aerodynamic countermeasures using 3D LES turbulence model. They proposed a method based on forced oscillations to identify the reduced velocity corresponding to the maximum amplitude of vibration.

The 3-bar simulation method was shown to be a simple and practical method for shear lag analysis of thin-walled box girders with constant depth and cross-section [122, 123]. Li et al. [124] combined this method with the transfer matrix method [125] to develop a 3-bar simulation-transfer matrix method for shear lag analysis of thin-walled box girders with constant or variable depth. It can be applied to continuous box girder bridges. Numerical results obtained by using this method were in good agreement with that of finite element software, ANSYS program.

Okamoto et al. [126] proposed a new type of steel box girder bridges partly stiffened by arch ribs. Safety of structural members was verified by the limits state design method. The ultimate and global buckling strength were obtained by the elastic-plastic large deformation analysis. The research concluded that the proposed bridge has sufficient resistance against bending, axial forces and global buckling. In addition, the new bridge is feasible and beautiful. Dowell and Johnson et al. [127] developed a new method which gives exact internal shear flows for RC and PC boxgirder bridge superstructure subjected to closed-form and compared to two methods of shear flow distribution. It was found that the closed-form equations provide exact results for cross-sections of any number of cells of arbitrary shapes, with or without symmetry. Djelosevic et al. [128] performed a research into the effect of local stress on the carrying capacity and optimum design of box girders- with rectangular cross-section. Mathematical formulation was performed to enable the definition of the local stress state by the analytical procedure. Verification of the calculation values as well as of the applied methodology was carried out by means of FEM, using ANSYS 12 software.

Nguyen et al. [129] proposed a MATLAB optimization toolbox-based approach for analyzing reliabilitybased design optimization (RBDO) problems with emphasis on prestressed concrete (PC) box girder 
bridges under the attack of pitting corrosion. Savkovic et al. [130] proposed an optimum solution to optimization of the box section of the main girder of the bridge crane. Reduction of the girder mass was set as the objective function. Optimum dimensions of the box section were defined analytically using the method of Lagrange Multipliers. Using the obtained optimum values, it was shown, by comparison with other solutions, that considerable saving in material consumed was made thus reducing its price. It was concluded that further research should be directed towards a multi-criteria analysis where it would be necessary to include additional constraint functions.

Simplified methods and miscellaneous methods have the following limitations. Simplified methods are prone to errors of varying degrees. The approximations involved reduce the methods to very limited usage. The reliability of such methods is doubtful in predicting the local variations of stress which are characteristic of box girder bridge decks. Most of the miscellaneous methods used in the analysis of box girder bridges are peculiar to particular cases of analysis and, therefore, cannot easily be generalized for wider applications.

\subsection{Experimental Studies}

The main objective of experimental studies is to examine the validity of theoretical formulations and computer programs to investigate the behavior of box girder bridges. Few experimental investigations in box girder bridges have been conducted in comparison to the numerous analytical studies. In addition few authors have reported on field testing of existing box girder bridges to validate the existing methods of elastic analysis.

Aneja and Roll [131] tested a plastic model of a horizontally curved box beam highway bridge and compared the results to a finite element analysis. The comparison showed close agreement between the shapes but not the magnitude of the stress plots. Arizumi et al. [99] tested three models of curved composite box girders. The measurements obtained from the test were compared to the finite strip method and Dabrowski's $[16,17,18]$ distortion theory. The results were in good agreement. Shanmugam and Balendra [132] tested elastically two, Perspex, cellular models of different span-to-radius ratios subjected to different loading conditions to examine the results obtained from a finite-element modeling. Yabuki et al. [68] investigated the effect of plate buckling and distortion on the ultimate strength of curved box girders.

Kwak et al. [133, 134] conducted experimental and theoretical investigation on the effects of the slab casting sequences and drying shrinkage of concrete slabs on the short-term and long-term behavior of composite steel box girder bridges. The effect of drying shrinkage was found to be much more important than the concrete casting sequence. Field recommendations in terms of concrete slump and relative humidity were suggested to prevent early transverse cracking of concrete slabs. Luo et. al. [135] investigated the shear lag phenomenon of box girders using three Perspex glass models. The experiments addressed two issues, the beam-column action and the effect of varying depth upon the shear lag of box girders. In general the experimental results match reasonably well with the numerical predictions. However, there are some noticeable differences. In some cases, the difference in the stress predicted by the finite element method and the experimental results can be as high as $25 \%$. Choi et al. [136] used a system identification technique to evaluate the rate of possible structural property changes of a reinforced concrete box girder bridge, the Lavic Road bridge in California, monitored over a 2-year period from December 1997 to October 1999. The validation of the system identification scheme was demonstrated through a numerical study using the finite element model of some of the bridge structure.

Huang [137] presented the field test result of Arlington Bridge, a comparatively large radius bridge, located at Jacksonville, Fla. Huang [138, 139] conducted dynamic test and analysis of curved steel box girder bridges. Also, Huang et al. [140] and Huang [141] presented the result of field tests conducted on the Veteran's Memorial Curved Steel Box Girder Bridge. The objectives of the study were to identify the actual static and dynamic behaviours of such bridges and provide more reasonable load rating capacities for existing bridges. Tests and analytical results show, among other things, that the current AASHTO guide specifications regarding the first transverse stiffener spacing at the simple end support of a curved girder may be too conservative for bridge load capacity rating.

Pindado et.al [142] tested different types of bridge cross-sections to analyze the yawing moment acting on the box-girder deck of reinforced concrete bridges constructed using the balanced cantilever method. Experimental results show that the yawing moment 
coefficient decreases as the bridge decks becomes streamlined, and that the yawing moment coefficient reaches a maximum when the bridges deck length is nearly twice the deck width. Kurian and Menon [143] tested a $1 / 5$ scale simply supported reinforce concrete box girder bridge to study collapse mechanism in the presence of cross-sectional distortion. The study proposed a modification to the existing theory. It concluded that the modified theory to predict the collapse load match very closely with experimental results. Ashembo et at. [144, 145] presented the results of field test modal analysis on a skew box girder continuous bridge. It was found that the influence of skew in both the static and dynamic behaviors of the bridge within the skew angle range of $0^{0}-30^{0}$ is very small. Also dynamic load factor obtained in this study for vehicle-induced dynamic loads is less than values provided by most bridge design codes.

Naito et. al. [146] conducted field investigation and tests of unexpected damage to a three-span continuous-spread prestressed box beam bridges after 12 years of service. The bridge was designed in 1986 and placed in service in 1989 in Pennsylvania. The conclusion was that the cracks in the beams developed from a combination of conditions created by design, detailing, and production of the beams. Liu et al. [147] developed a baseline for structural health monitoring for a curved post- tensioned concrete box-girder bridge using field testing data and finite element model. A good agreement in modal results was observed between the baseline finite element model and the baseline field data. The proposed structural health baseline could be used for near real-time damage detection, development of monitoring techniques, and condition assessment.

Sasaki et al. [148] carried out field and experimental investigation on the failure of concrete T-beam and box-girder highway bridges subjected to cyclic loading from traffic. Several factors were identified as contributors to the failure mechanism, including high volume of heavy truck traffic, and transverse moments caused by unbalanced wheel loading. The study concluded that further research should be conducted to develop design requirements since the current design codes do not address these cyclic effects. Fam and Honickman [149] developed a novel built-up GFRP box girder using hat-shape trapezoidal sections along with flat GFRP plates and cast-in-place concrete slab. The study demonstrated the feasibility of fabrication and they presented the flexural performance of the system. They concluded that the GFRP box-girder with adhesively and mechanically bonded concrete slab showed $87 \%$ higher flexural strength and $112 \%$ higher stiffness than the bare GFRP box girder (without a slab). Chung and Kim [150] investigated the dynamic performance of a spliced Pre-Stressed Concrete (PSC) box girder that used a longitudinal splicing technique as an effective method to accelerate Pre-Stressed Concrete (PSC) bridge construction. The dynamic characteristics of the spliced girder were directly compared and evaluated against the monolithically-cast girder. Based on experimental results it was concluded that the splicing technique used provides similar dynamic characteristics to those of the monolithic girder. It was recommended that the spliced girder would be an effective tool for the future rapid construction of PSC railway bridges.

$\mathrm{Li}$ et.al [124] investigated the vortex-induced vibration of a twin steel box girder suspension bridge with a centre span of $1650 \mathrm{~m}$ based on field measurements. The research concluded that vertical vortex-induce resonance of the deck might occur with the wind direction nearly perpendicular to the longitudinal bridge axis and a low turbulence intensity in the wind speed range of $6-11 \mathrm{~m} / \mathrm{s}$. Xu et al. [151] carried out experimental study on double composite action in the negative flexural region of two-span continuous composite box girder. Two continuous composite girders were designed to study the mechanical properties in concrete crack, formation of sectional plastic hinge, load-carrying capacity, etc. Results of the analysis indicated that double composite action made concrete crack development slower in service stage.

He et al. [152] summarized the results of a research project that encompassed 1:8 scale model testing and analyses of a three-span continuous, prestressed concrete (PC), box girder bridge having a $45^{\circ}$ skew. The scale-model structure replicates an actual bridge being constructed for a high speed railway in China between Beijing and Shanghai. The influence of skew on the bridge's static and dynamic behavior was investigated. Research results provide important scientific basis for the design and construction of skewed bridges on high speed railways. Hodson et. al. [153] carried out a static live-load test of a typical boxgirder bridge. Based on the results of the parametric study using the calibrated finite-element modeling scheme, a new equation, which more accurately predicts the exterior girder distribution factor, was 
proposed. Lu et al. [154] presented a model test of $1 / 30$ scale and numerical finite element analysis (FEA) on the mechanical behavior of a typical composite box girder bridge. The results of the finite element analysis were in good agreement with those of the tests in terms of strength and stiffness. Guo and Chen [155] presented the long-term stress monitoring on several fatigue-prone details of Fort Duguesne Bridge, a 40year old steel bridge built in 1969 across the Alleghney River in Pittsburgh, Pennsylvania. Based on the study a probabilistic fatigue assessment procedure was proposed, which combines the long-term SHM (Structural Health Monitoring) and the LEFM (Linear Elastic Fracture Mechanics). It was concluded that some unique bridge details could be evaluated with regards to their fatigue reliabilities, using the proposed procedure.

Experimental studies have the following shortcomings. Experimental investigations in box girder bridges are generally much more capital intensive than analytical studies. Therefore, experimental studies in this regard are naturally restricted by the availability of finance, equipment, expertise and the bridge or its prototype model.

\section{SALIENT PROMPTS FROM EXISTING WORK}

The literature review point to the following important facts:

i. Little consideration has been given to continuous and multi-cell box girder bridges.

ii. Further research works is, therefore, recommended for the analysis of continuous and multi-cell box girder bridges.

iii. Shear deformation of the flanges has considerable effect on box girder bridges subjected to load but discrepancies in numerical results of the shear lag effects are still observed in literature. More research efforts are still need in this regard.

iv. Shear deformations of the web is given less attention.

v. Most analytical methods for box girder bridges are very complex and so the methods that are more amenable to computer application are recommended.

vi. The finite element method is regarded as the most general and comprehensive technique for the analysis of most continuum structures including box girder bridges. It is however computationally expensive and time-consuming. vii. For a prismatic isotropic structure, like the box girder bridge, with constant cross-section that do not change transversely, structural analysis can be performed advantageously using finite strips instead of finite element.

viii. Though most of the experimental studies are satisfactory they are very few compared to the numerous analytical studies.

\section{PROPOSED METHOD FOR ANALYSIS OF BOX- GIRDERS}

The proposed method to be applied for the analysis of box-girders should be varied and less demanding such that their designs can be sufficiently implemented or achieved, if not completely, and irrespective of the type or isotropy or anisotropy, material of construction, support conditions, skew, service life, to mention but a few.

It would seem that the FEM is most appropriate as it is powerful and generates most of the solutions. However, some parameters are still not fully accounted for especially in the complete determination of shear lags at corners and stiffeners, skew and results could be misinterpreted.

The proposed method of analysis should include a stochastically generated FEA method, which will incorporate the benefits of ease of application, optimization of the requirements of relevant codes, savings in time and computation efforts and with practical interpretation and application of the results. It should not be restricted but have a wide application that transcends all major codes of design world-wide.

For bridges having regular geometric plans and simple boundary conditions, a full finite element analysis is often both extravagant and unnecessary in which case the FSM would be preferable.

\section{CONCLUSION}

Various works have been carried out by many researchers towards the efficient analysis and design of box-girder bridges. The solutions suggested have not resulted into a holistic and comprehensive analysis and design of these types of structures. However, much work need be done. These will include the application of a method that is stochastically oriented with less computation and ease of operation, whose results are simple and all- 
encompassing while defining and detailing the loads and corresponding resistances (for example, a combination of FEM and FSM in a probabilistic environment), safe, economical and reliable.

The method to be employed should be varied and incorporating authentic computer simulation and results of experimental investigation in order to achieve sufficient level of design, predicting safety and economy for box-girder bridges.

\section{REFERENCES}

1. Maisel, B. I. (1970). Review of literature related to the analysis and design of thin-walled beams, Tech. Rep. No. 42440, Cement and Concrete Association, London.

2. Swann, R.A. (1972), A feature survey of concrete spine-beam bridges, Technical Rep. No. 42.469, Cement and Concrete Association, London.

3. Maisel, B. I., Rowe, R. E. and Swann, R. A. (1973). Concrete box girder bridges, Struct. Eng. 51(10), pp. 363-376.

4. Maisel, B. I. (1982). Analysis of concrete box beams sing small-computer capacity, Cement and Concrete Association.

5. Sennah, K. M. and Kennedy, J. B. (2001), State-ofthe-Art in Design of Curved Box-Girder Bridges, J. of Bridge Engineering, 6 (3), pp.159-166.

6. American Association of State Highway and Transportation Officials (AASHTO). (1993), Guide Specifications for Horizontally Curved Highway Bridges, as revised in 1981, 1982, 1984, 1985, 1986, 1990, and 1992. Washington, D. C.

7. Canadian highway bridge design code (CHBDC). (2000). Ontario Ministry of Transportation and Communications, Downsview, Ontario, Canada.

8. Sennah, K. M. and Kennedy, J. B. (2002), Literature Review in Analysis of Box Girder Bridges, J. of Bridge Engineering, 7 (2), pp. 134-143.

9. Davidson, J. S., Abdalla, R. S. and Madhavan, M., (2004), Stability of Curved Bridges During Construction, University Transportation Center of Alabama (UTCA), UTCA Report No. 03228, University of Alabama.

10. Kulicki, J. M., Wassef, W. G., Kleinhans, D. D., Yoo, C. H. Nowak, A. S., and Grubb, M. (2006), Development of LRFD Specifications for Horizontally Curved Steel Girder Bridges, National Cooperative Highway Research Program (NCHRP), NCHRP report 563, Washington.

11. St. Venant, B. (1843). Memoire sur le calcul de la resistance et al flexion des pieces solides a simple ou a double courbure, en prenant simultanement en consideration les divers efforts auxquels eiles peuvent entre soumises dans tous les sens, Compts Rendus, I'Academie des Sciences de Paris, Vol. 17, pp. 1020-1031 (in French).

12. Benscoter, S. U. (1954). A theory of torsion bending for multi-cell beams, J. Appl. Mech. 21(1) pp. 25-34.
13. Fan, Z. T., and Helwig, T. A, (2002), Distortional Loads and Brace Forces in Steel Box Girders, J. of Structural Engineering, 128(6), pp. 710-718.

14. Vlasov, V. Z. (1961). Thin-walled elastic beams, $2^{\text {nd }}$ Edition, National Science Foundation, Washington, D. C.

15. Vlazov, V. Z. (1965), "Thin-walled elastic beams" OTS61-11400, National Science Foundation, Washington, D.C.

16. Dabrowski, R., (1964). The Analysis of Curved ThinWalled Girders of Open Sections. Der Stahlbau, 33(12), pp. 364-372.

17. Dabrowski, R., (1965). Warping Torsion of Curved Box Girders of Non-Deformable Cross Section. Der Stahlbau, 34(5), pp. 135-141.

18. Dabrowski, R., (1968). Curved Thin-Walled Girders, Theory and Analysis. Translated from Germany by C. V. Amerongen, Cement and Concrete Association, Number 144, Springer Verlag, Berlin, Germany, 158 pps.

19. Mcmanus, P. F., Nasir, G. A., and Culver, C. G (1969). Horizontally curved girders state-of-the-art., Journal of structural Engineering, ASCE, Vol. 95, No ST 5, pp. 853-870.

20. Gottfeld, H. (1932). The Analysis of spatially curved steel bridges, Die Bautechnik, pp. 715 (in German).

21. Umanskii, A. A. (1948). Spatial Structures, Moscow (in Russian).

22. Kermani, B., and Waldron, P. (1993). Behavior of concrete box girder bridges of deformable crosssection, Proc., Inst. Civ. Eng., London, 99(2), pp. 109-122.

23. Razaqpur, A., Abbas H., El-Sammy, K., and Azab, M. (2000a). Dynamic Amplification factors of box girder bridges, Proc., Bridges Engineering Conf., Egyptian Society of Engineers, Sharm El-Sheikh Egypt, Vol. 1, pp. 633-644.

24. Razaqpur, A., Abbas, H., El-Sammy, K., and Azab, M. (2000b). Free vibration analysis of box girder bridges by thin-walled beam model, Proc., Bridge Engineering Conf., Egyptian Society of Engineers, Sharm El-Sheikh, Egypt, Vol. 1., pp. 621-632.

25. Wu, Y., Lai, Y., Zhang, X., and Zhu, Y., (2004), A Finite Beam Element for Analyzing Shear Lag and Shear Deformation Effects in Composite-Laminated BoxGirders, Computers and Structures, Elsevier, Vol. 82, pp. 763-771.

26. Park, N. H., Choi, S., and Kang, Y. J., (2005a), Exact Distortion Behavior and Practical Distortion Analysis of Multicell Box Girders Using an Expanded Method, Computers and Structures, Elsevier, Vol. 83, pp. 1607-1626.

27. Park, N. H., Choi, Y. J., and Kang, Y. J., (2005b), Spacing of Intermediate Diaphragms in Horizontally Curved Steel Box Girder Bridge, Finite Elements in Analysis and Design, Vol. 41, pp. 925-943.

28. Boresi, A. P., and Schmidt, R. J., (2005), Advanced Mechanics of Materials, $6^{\text {th }}$ Ed., John Wiley \& Sons Inc., India.

29. Guohao, L., (1987), Analysis of Box Girder and Truss Bridges, China Academic Publishers, Springer - Verlag, New York, NY

Vol. 34, No. 1, January 2015 
30. Heins, C. P. (1975), Bending and Torsional Design in Structural Members, Lexington Books, D.C. Health and Company, Lexington.

31. Nakai, H., and Yoo, C. H. (1988), Analysis and Design of Curved Steel Bridges, McGraw-Hill Book company, New York.

32. Osadede, N. N. and Mbajiogu, M. S. W. (2006), Distortional Analysis of Thin-Walled Box Girders, Nigerian Journal of Technology, University of Nigeria Nsukka, 25(2), pp. 36- 45.

33. Wright, R. N., Abdel-Samed, S. N., Robinson, A. R. (1968). BEF analogy for analysis of box girders. J. Struct. Div., ASCE, 94(7).

34. Kristek, V., (1968), Tapered box girders of deformable cross-section, J. Struct. Div., ASCE, 96 (8), Proc. Paper No. 7489.

35. Hsu,Y.T., Fu, C.C. and Shelling, D.R. (1995), EBEF Method for Distortional Analysis Of Steel Box Girder Bridges, J. of Structural Engineering, 121(3), pp. 557-566.

36. Cortinez, V.H., Piovan, M. T.,(1996), Discussion of "EBEF method for Distortional Analysis of Steel Box Girder Bridges" by Y. T. Hsu, C. C. Fu, and D. R. Schelling, J. of Structural Engineering, 121(3), pp. 982-984.

37. Scordelis, A. C. (1967), Analysis of Continuous Box Girder Bridges, Structure and material research, Report No. SESM-67-25, Department of Civil Engineering, College of Engineering, University of California, Berkeley.

38. Yang, L. F., Leung, A. Y. T. and Li, Q. S., (2001), The Stochastic Finite Segment in the Analysis of the Shear-Lag Effect on Box- Girders, Engineering Structures, Elsevier, Vol. 23, pp. 1461-1468.

39. Luo, Q. Z., Li, Q. S, Tang, J., (2002a), Shear Lag in Box Girder Bridges, J. of Bridge Engineering 7(5), pp.308-313.

40. Luo, Q. Z., Li, Q. S., Liu, D. K., and Yang, L. F. (2001a). A modified finite segment method for thin-walled single cell box girders with shear lag. Struct. and Build., Proc., Inst. Of Civ., Engrs., London, 146, pp. 41-49.

41. Luo, Q. Z., Tang, J., and Li, Q. S., (2001b), Negative Shear Lag Effect in Box Girders With Varying Depth, J. of Structural Engineering, 127, (10), pp.12361239.

42. Luo, Q. Z., Wu, Y. W., Li, Q. S., Tang, J., and Liu, G. D. (2004), A Finite Segment Model for Shear Lag Analysis, Engineering Structures, Elsevier, Vol. 26, pp. 2113-2124.

43. Wang, R. H., Li, Q. S. Wu, J. R, and Tang, J., (2005), $A$ Spatial Elastic Displacement Model for Curved Box Girder Bridges With Corner Stiffeners, Computers and Structures, Elsevier, Vol. 83, pp. 1021-1029.

44. Goldberg, J. E. and Leve, H. L. (1957). Theory of prismatic folded plate structures. Int. Assoc. Bridge Struct. Eng. J., Vol. 17, pp. 59-86.

45. DeFries-Skene, A., and Scordelis, A. C. (1964), Direct Stiffness Solution for folded plates, J. Struct. Div. ASCE. 90(4), pp. 15-47.

46. Al-Rifaie, W. N., and Evans H. R. (1979), An approximate method for the analysis of box girder bridges that are curved in plan. Proc., Int. Association for Bridge and Structural Engineering (IABSE), pp. 1-21.

47. Evans, H. R. (1984). Simplified methods for the analysis and design of bridges of cellular crosssection, Proc., NATO Advanced Study Institute on Analysis and Design of Bridges, Cesme, Izmir, Turkey,Vol. 74, pp. 95-115.

48. Marsh, J. G., and Taylor, P. (1990), PC program for orthotropic plate box girder bridges, Australia Second National Structural Engineering Conf., Institution of Engineers, Australia, pp. 224-235.

49. Dogaki, M., Harada, M., and Yonezawa, H. (1986). Elastic Buckling of Support Diaphragms with Rectangular Holes in Steel Box Griders, Technol, Rep. No. 27, Kansai University, Osaka, Japan.

50. Mikami, I., and Niwa, K. (1985). Ultimate Strength Test of Steel Box Girders with Unsysmmetrical Cross Section, Technol. Rep. No. 35, Kansai University, Osaka, Japan.

51. Oleinik, J. C. (1974). Design Criteria for distortional analysis of curved steel box beams, Masters Thesis, University of Maryland.

52. Oleinik, J. C., and Heins, C. P. (1975). Diaphram spacing requirements for curved steel box beam bridges, Journal of Structural Division, ASCE, 101(10), pp. 2161-2179.

53. Heins, C. P., and Oleinik, J. C. (1976). Curved box beam bridge analysis. Journal of Computers and Structures, Pergamon Press, Great Britain, Vol. 6, pp. 65-73.

54. Reissner, E., (1938), On the Problem of Stress Distribution in Wide Flanged Box Beam, J. Aero Sci., Vol. 5, pp. 295 - 9.

55. Reissner, E., (1941), Least Work Solutions of Shear Lag Problems, J. Aeronaut Sc., Vol. 8, pp. 284 - 91.

56. Reissner, E., (1946), Analysis of Shear Lag in Box Beam by Principle of Minimum Potential Engrg., Q. Appl. Math., 5 (3), pp. 268 - 78.

57. Kuzmanovic, B. O., and Graham, H. J. (1981). Shear lag in box girders, J Struct Div, ASCE, pp. 1701-1712.

58. Dezi, L., and Mentrasti, L. (1985). Nonuniform bending-stress distribution (shear lag), J Struct Eng, ASCE, 111(12), pp. 2675-2690.

59. Wu, Y. M, Luo, Q. Z, and Yue, Z. F. (2003). Energyvariational method of the shear lag effect in thin walled box girder. Eng. Mech, 20(4), pp. 161-5.

60. Yaping, W., Yualin, Z., Yuanming, L. and Weideng, P., (2002), Analysis of Shear Lag Deformation Effects in Laminated Composite Box Beams Under Bending Loads, Composite Structures, Elsevier, Vol. 55, pp. 147-156.

61. Hamed, E. and Frostig, Y., (2005), Free Vibrations of Multi-Girder and Multi-Cell Box Bridges With Transverse Deformations Effects, J. of Sound and Vibration, Elsevier, Vol. 279, pp. 699-722.

62. Wen, Q. J. (2011), Long-Term Effects Analysis of Prestressed Concrete Box-Girder Bridge Widening, J. of Construction And Building Materials, Elsevier, Vol.25, pp. $1580-1586$.

63. Rajagopalan, N. (2006), Bridge Superstructure, Narosa Publishing House Private Ltd., New Delhi. 
64. Ugale, T. V., Patel, B. A., and Mojidra, H. V. (2006), Analysis of Multicell Type Box Girder Bridges, Advances in Bridge Engineering, pp. 207-216.

65. Song, S. T., Chai, Y. H. and Hida, S .E. (2003), LiveLoad Distribution Factors For Concrete Box-Girder Bridges, J. Bridge Engineering, 8, (5), pp.273-280.

66. American Association of State Highway and Transportation Officials (AASHTO). (1998), AASHTO bridge design specifications, 2nd Ed., Washington, D. C.

67. Okeil, A. M., and El-Tawil, S. (2004). Warping Stresses in Curved Box Girder Bridges: Case Study, J. Bridge Engrg, 9(5), pp. 487-496.

68. Yakubi, T., Arizumi, Y., and Vinnakota, S. (1995). Strength of Thin-Walled Box Girders Curved in Plan. Journal of Structural Engineering, ASCE, 121(5), pp. 907-914.

69. Shu, H. S. and Wang, Y. C. (2001), Stability Analysis of Box-Girder Cable-Stayed Bridges, J. of Bridge Engineering, 6 (1), pp. 63-68.

70. Prokic, A., (2002), New Finite Element for Analysis of Shear Lag, Computers and Structures, Vol.80, pp. 1011-1024.

71. Prokic, A. (1996a). New warping Function for thinwalled beams. I: Theory, J Struct. Eng. (ASCE); 122(12): pp. 1437-42.

72. Prokic, A. (1996b). New warping function for thinwalled beams. II: Finite element method and applications. J. Struct. Eng. (ASCE); 122(12); pp. 1443-52.

73. Lee, S. C., Yoo, C. H. And Yoon, D. Y. (2002), Analysis of Shear Lag Anomaly in Box Girders, ,J. Structural Engineering, 128 (11), pp. 1379-1386.

74. Lee, S. C., Yoo, C. H. and Yoon, D. Y. (2004), Closure to "Analysis of Shear Lag Anomaly in Box Girders" by S. C. Lee, C. H. Yoo, And D. Y. Yoon, J. of Structural Engineering, 130(11), pp. 1861-1862.

75. Rovnak, M. and Duricova, A. (2004), Discussion of "Analysis of Shear Lag Anomally in Box Girders" by S.C. Lee, C.H. Yoo, and D.Y. Yoon, J. structural Engineering, 130 (11), pp. 1860.

76. Rovnak, M., and Duricova, A. (2003). Discussion of Negative Shear lag effect in box girders with varying depth by Q. Z. Luo J. Tang and Q. S. Li J. Struct. Eng. 129(2), pp. 269-271.

77. Rovnak, M., and Rovnakova, L., (1996). Discussion of "Negative Shear lag in framed-tube buildings" by Y. Singh and A. K. Nagpal J. Struct. Eng. 122(6), pp. 711-712

78. Lertsima, C., Chaisomphob, T., and Yamaguchi, E., (2004), Stress Concentration Due to Shear Lag in Simply Supported Box Girders, Engineering Structures, Vol. 26, pp. 1093-1101.

79. British Standard Institution. (1982). Steel, Concrete and Composite Bridges, Bs 5400, Part 3 Code of Practice for design of composite bridges, London.

80. Deutsches Institut fur Normung. (1981). Concrete Bridges, Design and Construction, DIN 1075, Berlin.

81. Japan Road Association. (2002). Design specifications for highway bridges, Part II Steel Bridges, Tokyo, Japan.
82. Yoon, D. Y., Lee S. C. and Yoo, C. H. (2005), Analytical Investigation of Access Hole in LoadBearing Diaphragms of Steel Box Girders. J. of Constructional Steel Research, Elsevier, Vol.61, pp. 113-131.

83. Kurian, B. and Menon, D. (2005), Correction of Errors in Simplified Transverse Bending Analysis of Concrete Box-Girder Bridges, J. of Bridge Engineering, 10(6), pp. 650-657.

84. Zhou, S. J. (2010). Effect of Shear Lag on Structural Behavior in Indeterminate Box-Girders, J. Civ., Architectural, Environ. Eng., 32(4), pp. 7-11.

85. Zhang, Y. and Luo, R. (2012), Patch Loading and Improved Measures of Incremental Launching of Steel Box Girder, J. of Constructional Steel Research, Elsevier, Vol.68, pp. 11-19.

86. Kim, Y. J. and Fam, A. (2011), Numerical Analysis of Pultruded GFRP Box Girders Supporting Adhesively-Bonded Concrete Deck in Flexure, Engineering Structures, Elsevier.

87. American Association of State Highway and Transportation Officials (AASHTO). (2007), AASHTO LRFD bridge design specifications, $4^{\text {th }}$ Ed., Washington, D. C.

88. Lei, M., Linyun, Z., Shuqin L., and Shui, W. (2012), Eccentric Load Coefficient of Live Load Normal Stress of Continuous Composite Box-Girder Bridge With Corrugated Steel Webs, Procedia Earth and Planetary Science, Elsevier, Vol.5, pp.335-340.

89. Ding, Y., Jiang, K. and Liu, Y. (2012), Nonlinear Analysis for PC Box-Girder With Corrugated Steel Webs Under Pure Torsion, Thin-Walled Structures, Elsevier, Vol. 51, pp. 167-173.

90. Ovesy, H. R, Ghannadpour, S. A. M., and ZiaDehkordi, E. (2013), Buckling Analysis of Moderately Thick Composite Plates and Plate Structures Using an Exact Finite Strip, Composite Structures, Elsevier, Vol. 95, pp. 697-704.

91. Cheung, M. S., Li, W. and Chidiac, S. E. (1996), Finite Strip Analysis of Bridges, $1^{\text {st }}$ Ed., E \& FN SPON, London.

92. Choi, C. K., Kim, K. H. and Hong, H. S. (2002), Spline Finite Strip Analysis of Prestressed Concrete BoxGirder Bridges, Engineering Structures, Elsevier, Vol.24, pp. 1575-1586.

93. Halkude, S. A. and Akim, C. Y. (2012), Analysis of Straight and Skewed Box Girder Bridge by Finite Strip Method, International J. of Emerging Technology and Advanced Engineering, (IJETAE), 2(11), pp. 191-198.

94. Cheung, Y.K. (1976), Finite Strip Method in Structural Analysis, $1^{\text {st }}$ ed., Pergamon Press, Oxford.

95. Cheung, Y.K. (1969), Finite Strip Analysis of Simply Supported Box Girder Bridges.

96. Cheung, M. S. and Cheung, Y. K (1971). Analysis of curved box Girder Bridge by the finite strip method. International Association for Bridges and Structural Engineering (IABSE), 31(1), pp. 1-8.

97. Cheung, Y.K., Cheung, M. S, and (1982). Spline Finite Strip Analysis of Box Girder Bridges. 
98. Cheung, Y. K., and Fan, S. C. (1983). Static Analysis of Right Box Girder Bridges by Spline Finite Method, Proc. Inst. Civ. Eng., 2(75), pp. 311-323.

99. Arizumi, Y., Hamada, S., and Oshiro, T. (1988). Behavior Study of Curved Composite Box Girders, J. of Structural Engineering, ASCE, 114(11), pp. 25552573.

100. Bradford, M. A., and Wong, T. C. (1992). Local Buckling of Composite Box Girders under Negative Bending. Journal of Structural Engineering, 70(21), pp. 377-380.

101. Taysi, N. and Ozakca, M. (2002), Free Vibration Analysis and Shape Optimization of Box-Girder Bridges in Straight and Curved Planform, Engineering Structures, Elsevier, Vol.24, pp. 625637.

102. Ezeokpube, G. C. (2013). Finite Strip Analysis of Continuous Thin-Walled Box girder Bridges, PhD Thesis, University of Nigeria Nsukka (UNN).

103. Loo, Y. C. and Cusens, A. R. (1978), The Finite Strip Method in Bridge Engineering, Viewpoint Publications, Cement and Concrete Association,Wexham Springs.

104. Cheung, Y. K. and Tham, L. G. (1998), Finite Strip Method, CRC press LLC, Washington, D.C.

105. Knittle, G., (1965). The analysis of thin-walled boxgirders of constant symmetrical cross-section, Beton-und Stahlbetonbau, pp. 205-211. Available as Cement and Concrete Association Library Translation, November 1974, 42. 494.

106. Richmond, G. (1966). Twisting of Thin-Walled BoxGirders, Proc. Inst. Civ. Eng., pp 659-675.

107. Kupfer, H. (1969). Box beams with elastically stiffened cross section under line and point loads, G. Knittle and H. Kupfer, eds., W. Ernst u. Sohn, Berlin, pp. 251-263. Available as Cement and Concrete Association Library Translation, 1974, 42. 494.

108. Tung, D. H. H., and Fountain, R. S. (1970). Approximate torsional analysis of curved box girders by $M / R$-method, Engineering Journal, American Institute of Steel Construction, 7(3), Chicago, IL, pp. 65-74.

109. Chang, S. T., and Zheng, F. Z. (1987). Negative shear lag in cantilever box girder with constant depth, J. Struct. Div. ASCE, 113(1), pp. 20-35.

110. Chang, S. T. (2004), Shear Lag Effect in Simply Supported Prestressed Concrete Box Girder, J. of Bridge Engineering, 9(2), pp. 178-184.

111. Galuta, E.M. and Cheung, M.S., (1994), Combined Boundary Element and Finite Element Analysis of Composite Box Girder Bridges, Computers and Structures, Pergamon, 57 (3), pp. 427-437.

112. Oh, B. H. and In, I.H. (2001), Realistic Long-Term Prediction of Prestress Forces in PSC Box Girder Bridges. J. of Structural Engineering, 127 (9), pp.1109-1116.

113. Chusilp, P. and Usami, T., (2002), Strength and Ductility of Steel Box Girders Under Cyclic Shear, J. of Structural Engineering, 128(9), pp.1130-1138.

114. Luo, Q. Z., Tang, J. and Li, Q. S. (2003), Calculation of Moment on Top Slab in Single-Cell Box Girders, J. of Structural Engineering, 129 (1), pp. 130-134.
115. Upadyay, A. and Kalyanaraman, V. (2003), Simplified Analysis of FRP Box-Girders, Composite Structures ,Elsevier, Vol. 59, pp. 217-225.

116. Rovnak, M., and Duricova, A. (2003). Discussion of Negative Shear lag effect in box girders with varying depth by Q. Z. Luo J. Tang and Q. S. Li J. Struct. Eng. 129(2), pp. 269-271.

117. Matsumoto, M. et al. (1997). Study on aerodynamic behavior of long-span bridge and its stabilization, Technical Report BWKU Y96640, Department of Global Environment Engineering, Kyoto University, Japan, 1997.

118. Yang, W. Y., Cao W., Cung Tae-Sung, and Morris J., (2005) Applied Numerical Methods Using MATLAB, John Wiley \& Sons, Inc., Hoboken, New Jersey.

119. Moon, D. Y., Sim, J., and Oh, H. (2005), Practical Crack Control During the Construction of Precast Segmental Box Girder Bridges, Computers and Structures, Elsevier, Vol.83, pp. 2584-2593.

120. Mori, T., Lee, H. H., and Kyung, K. S. (2007), Fatigue Life Estimation Parameters for Short and Medium Span Steel Highway Girder Bridges, Engineering Structures, Elsevier, Vol. 29, pp.2762-2774.

121. Sarwar, M. W. and Ishihara, T. (2010), Numerical Study on Suppression of Vortex-Induced Vibrations of Box Girder Bridge Section by Aerodynamic Countermeasures, J. of Wind Engineering and Industrial Aerodynamics, Elsevier, Vol.98, pp. 701711.

122. Wang, H D., Qiang, S. Z. (2006). 3-bar simulation method for cantilever box girder under compactbending load, Journal of Agricultural University of Hebei, 29(6), pp. 108-113.

123. Zhang, S. T., and Wang, W. Z. (2004). Negative shear lag in bridge construction, Beijing, China Communication Press, pp. 113-130.

124. Li, H., Laima, S., Ou, J., Zhao, X., Zhou, W., Yu, Y., Li, N., and Liu, Z., (2011), Investigation of VortexInduced Vibration of a Suspension Bridge With Two Separated Steel Box Girders Based on Field Measurements, Engineering Structures, Elsevier, Vol. 33, pp. 1894-1907.

125. Wei, C. L., Li, B., Zeng, Q. Y., (2008). Transfer Matrix Method Considering Both Shear Lag and Shear Deformation Effects in Non-uniform Continuous Box Girder, Engineering Structures, 25(9), pp. 111117.

126. Okamoto, Y., Nakamura, S., Tanaka, H., and Moriya, Y., (2012), Study on Steel Box Girder Bridges Partly Stiffed by CFT Arch Ribs, J. of Constructional Steel Research, Elsevier, pp. 28-35.

127. Dowel, R. K. and Johnson, T. P. (2012), Closed-Form Shear Flow for Box-Girder Bridges Under Torsion. Engineering Structure, Vol. 34, pp. 383-390.

128. Djelosevic, M., Gajic, V., Petrovic, D. and Bizic, M. (2012), Identification of Local Stress Parameters Influencing the Optimum Design of Box Girders, Engineering Structures, Elsevier, Vol. 40, pp. 299316.

129. Nguyen, V. S., Jeong, M. C., Han, T. S. and Kong, J. S. (2013), Reliability-Based Optimization Design of Post-Tensioned Concrete Box Girder Bridges 
Considering Pitting Corrosion Attack, Structure and Infrastructure Engineering, 9(1), pp. 78-96.

130. Savkovic, M. M., Gasic, M. M., Catic, D. M., Nikolic, R. R., and Pavlovic, G. V. (2013), Optimization of the Box Section of the Main Girder of the Bridge Crane With the Rail Placed Above the Web Plate, Struct Multidisc Optim, Vol. 47, pp. 273-288.

131. Aneja, I. K., and Roll, F. (1971). A Model Analysis of Curved Box-Beam Highway Bridges. J. Struct. Div., 97(12), pp. 2861-2878.

132. Shanmugam, N. E., and Balendra, T. (1991). Experimental and Theoretical Study of Multi-Cell Structures Curved in Plan. Thin-Walled Struct., 12(5), 373-387.

133. Kwak, H. G., Seo, Y. J., and Jung, C. M., (2000a), Effects of the Slab Casting Sequences and the Drying Shrinkage of Concrete Slabs on the ShortTerm and Long-Term Behavior of Composite Steel Box Girder Bridges. Part 2, Engineering Structures, Elsevier, vol 23, pp.1467-1480.

134. Kwak, H. G., Seo, Y. J., and Jung, C. M., (2000b), Effects of the Slab Casting Sequences and the Drying Shrinkage of Concrete Slabs on the Short-Term and Long-Term Behavior of Composite Steel Box Girder Bridges. Part 1, Engineering Structures , Elsevier, Vol. 23, pp. 1453-1466.

135. Luo, Q. Z., Wu, Y. W., Tang, J, and Li, Q. S. (2002b), Experimental Studies on Shear Lag of Box Girders, Engineering Structures, Elsevier, Vol. 24, pp. 469477.

136. Choi, S., Park, S., Bolton, R., Stubbs, N. and Sikorsky, C. (2004), Periodic Monitoring of Physical Property Changes in a Concrete Box-Girder Bridge, J. of Sound and Vibration, Elsevier, Vol. 278, pp.365381.

137. Huang, D. Z. (2004). Field test and rating of Arlington curved steel box girder bridge, Transportation Research Record, No. 1892, Transportation Research Board, Washington, D. C.

138. Huang, D. Z. (2001). Dynamic Analysis of Steel Curved Box Girder Bridges, Journal of Bridge Engineering, ASCE, 6(6).

139. Huang, D. Z. (2005). Dynamic test and analysis of curved steel box girder bridges, Transportation Research Record, No. 1928, Transportation Research Board, Washington, D.C.

140. Huang, D. Z., Ansley, M., Roufa, G. (2004), "Bridge testing report Veteran's Memorial Bridge “, Rep. No. SRC-H001-04, Florida Department of transportation, Structures Research Center, Tallahassee, Fla.

141. Huang, D. Z. (2008), Full-Scale Test and Analysis of a Curved Steel-Box Girder Bridge, J. of Bridge Engineering, 13(5), pp. 492-500.

142. Pindado, S., Meseguer, J., and Franchini, S., (2005), The Influence of the Section Shape of Box-Girder Decks on the Steady Aerodynamic Yawing Moment of Double Cantilever Bridges Under Construction, J. of Wind Engineering and Industrial Aerodynamics, Vol. 93, pp. 547-555.
143. Kurian, B. and Menon, D. (2007), Estimation of Collapse Load of Single Cell Concrete Box-Girder Bridges, J. of Bridge Engineering, 12 (4), pp. 518526.

144. Ashebo, D. B., Chan, T. H. T., and Yu, L. (2007a), Evaluation of Dynamic Loads on a Skew Box Girder Continuous Bridge, Part I: Field Test and Modal Analysis, Engineering Structures, Elsevier, Vol.29, pp. 1052-1063.

145. Ashebo, D. B., Chan, T. H. T., and Yu, L., (2007b), Evaluation of Dynamic Loads on a Skew Box Girder Continuous Bridge, Part II: Parametric Study and Dynamic Load Factor, Engineering Structures, Elsevier, Vol. 29 (6), pp.1064-1073.

146. Naito, C., Sause, R. and Thomson, B. (2008), Investigation of Damaged 12-Year Old Prestressed Concrete Box Beams, J. of Bridge Engineering, 13(2), pp. 139-148.

147. Liu, C., DeWolf, J. T. and Kim, J. H. (2009), Development of a Baseline for Structural Health Monitoring for a Curved Post-Tensioned Concrete Box-Girder Bridge, Engineering Structures, Elsevier, Vol. 31, pp. 3107-3115.

148. Sasaki, K. K., Paret, T. Ariaza, J. C. Hals, P. (2010), Failure of Concrete T-Beam and Box-Girder Highway Bridges Subjected to Cyclic Loading from Traffic, Engineering Structures, Elsevier, Vol. 32, pp. 1838-1845.

149. Fam, A., and Honickman, H. (2010), Built-up Hybrid Composite Box Girders Fabricated and Tested in Flexure, Engineering Structures, Elsevier, Vol. 32, pp. 1028-1037.

150. Chung, W. and Kim, S. M. (2011), Comparison of Dynamic Properties of Spliced and Monolithic Prestressed Concrete Box Railway Girders, Engineering Structures, Elsevier, Vol. 33, pp. 17731780.

151. Xu, C., Su, Q., Wu, C., Sugiura, k. (2011), Experimental Study on Double Composition Action in the Negative Flexural Region of Two-Span Continuous Composite Box Girder, J. of Constructional Steel Research, Elsevier, Vol. 67, pp. 1636-1648.

152. He, X. H., Sheng, X. W., Scanlon, A., Linzell, D. G., Yu, X. D. (2012), Skewed Concrete Box Girder Bridge Static and Dynamic Testing and Analysis, Engineering Structures, Elsevier, Vol.39, pp. 38-49.

153. Hodson, D. J., Barr, P. J., and Halling, M. W. (2012), Live-Load Analysis of Post-tensioned Box Girder Bridges, J. of Bridge engineering, 17(4), pp. 644651.

154. Lu, P. Xie, X., Shao, C., (2012), Experimental Study and Numerical Analysis of a Composite Bridge Structure, Construction and Building Materials, Elsevier, Vol. 30, pp. 695-705.

155. Guo, T. and Chen, Y. W. (2013). Fatigue Reliability Analysis of Steel Bridge Details Based on FieldMonitored Data and Linear Elastic Fracture Mechanics, Structures and Infrastructure Engineering, 9(5), pp. 496-505. 